\title{
CHINA'S METHOD OF REVISING HER EDUCATIONAL SYSTEM
}

\author{
By F. L. Hawks Potr, D.D., \\ President of St. John's University, Shanghai.
}

In order to appreciate fully the magnitude of the task undertaken by China, and to get some adequate idea of the difficulties to be overcome, it is necessary to sketch in outline the old educational system as it existed before the reform movement began to make itself felt.

The first thing to be borne in mind is that, strictly speaking, originally there were no government schools in the Chinese Empire. With the exception of a few schools for Banner men, the clan of the reigning Manchu Dynasty, in Peking, education was left to private enterprise. The part played by the government in the educational system was the establishment of a series of examinations, corresponding in many ways to what we speak of as civil service competitive examinations. One of the chief aims of the private schools throughout the empire was to train up scholars who could pass these examinations successfully, and thus render themselves eligible for service in the government. The examinations had the effect of setting the standard of the educational system, and thus the same subjects and for the most part the same books were used in all the schools.

Any one could set up as a school teacher, and a great many scholars who had attained the first degree in the government examinations and a host of others who had tried and failed made this their chief means of obtaining a living. The scholars in the school paid small fees, and the life of a teacher was both penurious and laborious.

The course of study pursued in all schools was divided into three grades. First came the committing to memory the canonical books ${ }^{1}$ and the learning to write characters. Then followed the period when the textbooks were explained to the pupils and they received their first lessons in the art of composition. Lastly, they

The Four Books and the Five Classics.

(83) 
were taught to read more widely, especially collections of essays of successful scholars, and to write the sort of essay and poem which they would be required to compose at a government examination. Many of the pupils never advanced beyond the first or second stage, but those ambitious of going up to the examinations were bound to take the whole course. The result was to turn out young men thoroughly versed in the Confucian ethics, Mencian politics, and the history of China, with ability to write an elegant literary style, and to compose stiff and stereotyped verses.

The government examination system began as far back as the Tang Dynasty (618 A.D.) and has been continued ever since. Altogether there were four examinations.

The first were held in district cities, annually. About one per cent of the candidates who came up were successful. They were awarded the degree of Siu Tsai (Budding Talent) equivalent in some ways to our B.A. degree, but not signifying at all the general range of knowledge possessed by a graduate of an American college.

The second were held in provincial capitals, triennially. These were much severer tests. The candidates were immured in the little cells of the examination halls for three periods of three days each, and were put to a strain both physically and mentally which was an ordeal which few could pass through successfully. Here again the percentage of those who won the degree was low, only about one out of a hundred gaining the coveted degree of Chü-jên (Deserving of Promotion). Bearing in mind what we have said in regard to the first degree, we may compare the "Chü-jên" to the M.A. degree of the American university.

The third examinations were held in Peking triennially. Those who had secured the second degree were eligible, and if they could pass the third test were rewarded with the degree of Chin-shih (Fit for Office), corresponding in a way with our Ph.D. Two of the three examinations in this test were held in the presence of the emperor himself. The highest of the successful candidates were drafted off into government service, or were admitted into the College of the Hanlin (The Forest of Pencils). The position of the Hanlins corresponded to a certain extent to that of Fellows of an English university.

From this brief outline it will be seen that the whole system was intended to train men for public service. The conception of 
knowledge as a thing to be pursued for its own sake was overshadowed. The possibility of rising to be influential officials stirred the ambitions of a large number of the youth of the country, and led them to submit to the long process of intellectual training necessary to reach the goal.

Frequently the Chinese are referred to as an educated people. The statement is somewhat misleading. It would be fair to say that the Chinese hold education in high esteem, and that they look up to the scholar with great respect and reverence, but the system which has prevailed for all these centuries has only resulted in giving education to the chosen few. Among the poorer people there is a large amount of illiteracy. A fair estimate would be that only one in twenty of the male sex can read understandingly. The education of girls has been almost entirely neglected except among the richer people, and a woman who can read intelligently is regarded as a very rare phenomenon. Among artisans and small shopkeepers the amount of education possessed is only sufficient to enable them to read a few characters and to keep accounts. Even a knowledge of the characters sufficient for the reading of newspapers has not been acquired by the vast majority.

The inadequate system of education left the masses in appalling ignorance. This helps us to understand China's former conservatism and opposition to progress.

Having placed this picture before our minds, we will now proceed to describe the successive steps in the reform of the educational system.

The desire for reform manifested itself first in regard to the course of studies pursued by the scholars. Contact with Western nations opened the eyes of the Chinese to the fact that those who aspired to be the future officials of the empire needed other knowledge besides an acquaintance with the canonical books of China, and something more than the ability to write eight legged essays and stilted verses.

After the war with France (1884-1885) we note among the principal reforms then instituted that mathematics was introduced into the government examinations, and the attempt was made in this way to broaden the curriculum. Owing to the fact that the literary chancellors who presided over the examinations were themselves entirely ignorant of the new subject, very little, however, was 
accomplished in the way of modifying the old stereotyped classical examinations.

In 1872 a detachment of Chinese Government students was sent to the United States under the direction of Dr. Yung Wing. It was intended that they should receive a thorough education in American schools and colleges, and upon their return to China be instrumental in the introduction of reforms and of an enlightened system of education. Unfortunately the experiment was never carried out to completion, as all the young men were recalled just as they had reached the stage where they were ready to enter college.

The next step in the reform of the educational system was in connection with the reforms instituted by the late Emperor Kwang $\mathrm{Hsu}$ in 1898 . The young emperor was eager to abolish as far as possible the old classical examinations, and a decree was promulgated that henceforth those competing for degrees were to have "a knowledge of ancient and modern history, information in regard to the present-day state of affairs, with special reference to the governments and institutions of the countries of the five great continents, and a knowledge of the arts and sciences thereof."

It will be noticed that both in the proposals of 1885 and of I 898 nothing was said about the establishment of schools throughout the empire. The chief emphasis was laid upon the modification of the examination system in the direction of making it less antiquated.

Certain special schools, such as military and naval academies and some government colleges were established, but no steps were taken toward founding a government system of schools graded from the primary up to the university. ${ }^{2}$ This did not take place until after the period of reaction which resulted in the terrible upheaval of 1900 .

After the central government had been re-established in Peking the late empress dowager went over to the side of reform, and advocated the measures to which she had been so bitterly opposed before the Boxer outbreak.

A board of education was established in Peking in 1905, and an edict was issued abolishing the ancient system of government examinations. Largely under the direction of two high officials,

It should be noted that the only schools in the Chinese Empire up to a recent period giving a liberal education were those established by misslonaries. The missionaries may Justly claim to be the ploneers in the introduction of an enlightened system of education. 
Sun Chia-nai and Chang Chih-tung, a comprehensive scheme was worked out "which included the establishment of a central university in Peking, affiliated colleges, technical and normal schools in each provincial capital, high schools in each prefectural city, and primary schools in each departmental city and village."

The whole scheme, including regulations as to discipline, curricula, suggestions as to the method of establishing schools, etc., was carefully drawn up in a memorial submitted to the throne by H. E. Chang Chih-tung. When printed, it consisted of five volumes. The memorial was immediately approved, and the carrying out of the scheme was authorized by imperial edict.

This may be considered the beginning of the introduction of a national system of schools into the empire.

A careful perusal of these volumes shows that the memorialist was largely influenced by Japanese methods, and accounts for the similarity between the Chinese and Japanese systems of education.

The grading of schools is as follows:

I. The kindergarten and primary schools.

II. The first grade elementary school.

III. The high grade elementary school.

IV. The middle school.

V. The high school.

VI. The university.

The nomenclature is somewhat different from that to which we are accustomed. The middle school corresponds very closely to our grammar school, and the high school to the German gymnasium and the first years of the American college. The university follows the German idea and consists of eight special faculties.

In addition to the above general course of education, technical schools have also been established, some of them being included under the heading of middle or high schools, and others as being departments of a university. Provision was also made for normal schools.

In compiling the course of study, the attempt was made to provide for thorough instruction in the classical and historical literature of China, "thus enabling the new system of education to attach itself without too great a wrench to the earlier system which centered around civil service examinations." This, of course, made it necessary for the student to devote a good many hours of study 
to his own language and literature. To carry this burden in addition to acquiring the new Western learning overloads the student and is apt to result in superficiality. The problem of how to combine the new with the old is probably the greatest which the Chinese educator has to face. The system already adopted is probably more or less tentative, but if in drawing up the new schedule of studies no provision for the old learning had been made, the whole scheme would have been regarded as too revolutionary and would probably have failed to find favor in the eyes of the government.

Another feature in connection with the curricula adopted in the schools is the emphasis laid on ethical teaching. The Chinese have always entertained the idea that knowledge and morality are closely associated. The old system of training was intended to produce "the princely man," one who possessed intelligence but at the same time a perfectly rounded moral nature. The scholar of China in the past has been fond of expounding ethical principles and has posed as their embodiment. Too often it has been a case of video meliora proboque, deteriora sequor.

Real alarm has been felt lest the introduction of Western learning and a knowledge of the natural sciences would undermine the ethical principles upon which Chinese society is based, and consequently in the courses of study drawn up an important place has been given to moral culture.

The system having been settled, the question arose as to the best way of putting it into operation. It was an undertaking of tremendous proportions, nothing less than providing schooling for some $40,000,000$ boys and girls. As we have already indicated, everything had previously been left to private initiative, and the schools which existed were all the result of private enterprise. The government issues the edict "let there be these new schools," and it becomes the duty of officials and people to see that the mandate is carried out.

There never had been in China anything corresponding to school rates, and no provision had ever been made for assigning a part of the government revenue to educational purposes.

In the provincial governments the same was true, no regular allocation of a portion of the provincial revenue had ever been made to education.

The task of carrying out the will of the central government was 
laid upon the shoulders of the provincial authorities. The viceroys and governors had to assume this duty, and funds were secured in the following way: Some schools were founded by the officials themselves, who squeezed the money needed out of the provincial revenue, other schools were founded by money obtained from the people as contributions for this purpose. Still other schools were founded as acts of merit by wealthy gentlemen, who in return for this public service were rewarded by receiving some official rank,the right to wear the blue or red button.

As may be imagined, schools established in this way have had a somewhat precarious existence. The officials finding the cost more than they anticipated, have tried to curtail the expenditure, and the contributions from the people have sometimes not been forthcoming. Up to the present time, as will be seen later on when we quote statistics, very inadequate provision has been made for the education of the whole nation.

At the beginning of the reform, as was perhaps natural for those inexperienced in educational matters, the chief ain was to provide the schools of higher grade, and primary education was neglected. The government was in haste to produce the new scholar and seemed to think he could be manufactured in a short space of time. It was hoped that in this way the teachers for the primary school could be obtained. It soon became apparent, however, that the attempt to introduce the new education from the top was an impracticable one, and the need of establishing a large number of primary schools was realized. Recently more effort has been expended in this direction.

Another difficulty in the introduction of the new schools into China was in connection with securing qualified teachers. At first it was thought that the supply could be obtained by sending young men to study for a year or two in Japan. As many as twenty-five thousand young men, representative of the best type of learning under the old system, entered the schools of Japan, hoping to take a short cut to a knowledge of Western science. For a time a wave of enthusiasm swept over the country, and Japan was looked upon as the Mecca for those seeking enlightenment. In a short time, however, a reaction took place, and the Chinese became convinced that there was no royal road to learning, and that there must be the same patient toilsome labor as was required in the old system. 
The normal schools established in China have proved for the most part unsatisfactory, and the reason is not far to seek. The young men who have attended them never had the mental training in primary and elementary schools essential as a basis for more advanced work. A large number of subjects were taught in a superficial manner, and the men turned out for the most part have not proved efficient teachers.

Here, perhaps, we may say something in regard to the students sent for study to the United States and Europe. Realizing that it would be many years before the government could establish efficient higher education in the empire, the movement to select young men who have completed their elementary education in China, and to send them abroad for advanced study, has been encouraged. At first these young men were sent from each province at the expense of the provincial authorities. When the American Government decided to remit a portion of the Boxer indemnity, it was decided by the central government of China to employ the money, saved to her as the result of this act of generosity, in sending students to study in the United States. It was arranged that for five years one hundred young men should be sent annually, and after that fifty each year. A competitive examination was held in Peking for securing the best candidates. Three batches have already been sent, but, strange to say, the government thus far has never been able to secure the full quota. Last year a new method was adopted. This was the founding of a special school near the summer palace outside of Peking (the Ching Hua Hsioh-tang). A large number of American teachers was secured and a course of study was drawn up to prepare young men to pass the American college entrance examinations. The school has only been open for a short time, and thus it is too early to pass judgment upon it. It is hoped it will produce better results than the former method of selecting students from all schools throughout the empire by competitive examination.

The present status of the new system of education in China may be learned from the statistical reports submitted to the throne by the ministry of education, one in 1908 , and the other at the end of 1910 .

A comparison of these reports is interesting. In 1908 the number of students in provincial schools was $1,013,57 \mathrm{I}$, and at the 
end of last year $1,284,965$. Thus there was an increase of 274,518 . This included 3,95I more students in special studies, 4,923 additional students in industrial studies, and 265,644 more in ordinary studies. Students in training schools for teachers (normal schools) were 3,394 less in number.

The number of students in Peking showed an increase of about twenty-five per cent, the figures being 15,774 and II,4I7, respectively. There was a considerable increase in the number of schools. In the provinces there are now 42,444 as compared with 35,597 , and in Peking 252 as compared with 206. It also appears that when the first report was presented the number of government schools, those supported by officials, exceeded those supported by public contributors and private individuals, and that when the second report was sent in the public and private schools were more numerous than the government schools.

On the whole these reports are encouraging, but at the same time they show that China has only begun to grapple with the problem. In Japan, with a population roughly estimated at sixty millions, we find that about six million young people of school age are under instruction. If the same proportion, that is, about onetenth of the population, was provided with education in China, it would mean that forty million young people must be afforded school facilities. Thus far not as many as two million are to be found in the new schools and colleges.

We have already spoken of the grades of schools. We will now give a brief outline of the course of study in each grade.

\section{Kindergarten}

The aim of these schools is "to gather the children from three to seven years of age during certain hours of the day, to separate them from the dangers of the street, and to give them primary ideas of morality. These schools are free, and are to be established near orphanages and the homes of virtuous widows."

\section{The First Grade Elementary School}

The teaching includes morals, the study of the canonical books, the Chinese language, arithmetic, history, geography, physical sciences, and gymnastics. Children of seven years of age may enter 
these schools. The course is five years and there are thirteen hours class work per week.

\section{The High Grade Elementary School}

The subjects taught are the same as those in the first grade elementary school, with the addition of drawing. The study of foreign languages is forbidden except in schools situated in cities open to foreign trade. The course is four years and there are thirtysix hours class work per week.

\section{Middle School}

The instruction in these schools corresponds to what is called "Secondaire Moderne" in France, and the High School in the United States. The subjects studied are twelve in number, namely, morals, Chinese canonical books, foreign languages (Japanese or English compulsory, French, German or Russian optional), history, geography, mathematics, natural history, physics, chemistry, political economy, government, drawing and gymnastics. The singing of patriotic songs is to be taught both in the middle and the elementary schools. The course is five years, with thirty-six hours class work per week. Pupils who have obtained the diploma in the high grade elementary schools or who have passed an equivalent examination are admitted into the middle schools.

\section{High School}

The aim of the high schools is to prepare students to enter the university. There are three divisions corresponding to the three groups of faculties in the university. The students in the first section will be prepared for the faculties of classics, law, arts and commerce; in the second for the faculties of science, civil engineering and agronomy; and in the third for the faculty of medicine. All the scholars will study ethics, law, Chinese literature, foreign languages, and gymnastics. In addition to these, the students in the first section will study history, geography, elocution, law and political economy; the students of the second section, mathematics, physics, chemistry, geology, mineralogy and drawing; and those of the third section, latin, mathematics, physics, chemistry, zoology and botany. The foreign languages to be studied in the first and second 
sections are English, and French or German, and in the third section, German, and French or English. The course is three years, with six hours work in the classroom each day (thirty-six hours per week). Students who have obtained the diploma of the middle school or who have passed an equivalent examination are admitted into the high schools.

\section{The University}

The university is still in an embryonic condition, due to the lack of both students and professors. Eight faculties are to be established:

I. The faculty of Classics, comprising ten courses, among which are: (a) The Book of Changes, (b) The Book of Annals, (c) The Book of Poetry, (d) Spring and Autumn Annals, (e) Rites, $(f)$ Confucian Analects, and the Books of Mencius, with commentaries, $(g)$ Philosophy.

2. The faculty of Jurisprudence, with two courses: (a) Administration, (b) Legislation.

3. The faculty of Arts, comprising nine courses: (a) History of China, (b) Universal history, (c) General geography, (d) Geography of China, $(e)$ Geography of England, $(f)$. Geography of France, $(g)$ Geography of Germany, $(h)$ Geography of Russia, (i) Geography of Japan.

4. The faculty of Medicine, comprising two courses: (a) Medicine, (b) Pharmacy.

5. The faculty of Science, comprising six courses: $(a)$ Mathematics, (b) Astronomy, (c) Physics, (d) Chemistry, (e) Natural history, $(f)$ Geology.

6. The faculty of Agronomy, comprising four courses: (a) Agriculture, (b) Chemistry relating to agriculture, (c) Forestry, (d) Veterinary science.

7. The faculty of Engineering, comprising six courses: (a) Civil engineering, (b) Mechanical engineering, ( $c$ ) Electrical engineering, ( $d$ ) Architecture, $(e)$ Industrial chemistry, $(f)$ Mining engineering.

8. The faculty of Commerce, comprising three courses: (a) Banking and insurance, (b) Commerce and transportation, (c) Customs.

The course of study in the university is for three years except 
in medicine and law, in which it is four years. The students have from two to four hours class work per day.

Students who have secured diplomas in high schools may enter the university. The situation of the university is at Peking. If a province wishes to open a university, it may do so, provided it can establish at least three faculties.

Students who graduate from the university with high standing are allowed to do further post-graduate work for five years. Means will be provided to permit of their traveling abroad for purposes of study. Each year they must render a report of their work.

There are two grades of normal schools, the lower and the higher.

\section{The Lower Normal School}

The object is to train teachers for the first grade and high grade elementary schools. The subjects to be studied are morals, study and explanation of law, Chinese language, pedagogy, geography, history, mathematics, natural history, physics and chemistry, calligraphy, drawing and gymnastics. The course covers five years, each having forty-five weeks with thirty-six hours class work per week. Students who wish to enter these schools must have completed the high grade elementary school. According to local circumstances, one or more of the following subjects may be added: foreign languages, agriculture, commerce, manual training.

\section{Higher Normal Schools}

The object is to train teachers for the schools of higher grade. The course is three years, with thirty-six hours class work per week. The subjects in the first year are the same for all students, but in the last two years the students are divided into four courses: (a) languages, (b) history and geography, (c) mathematics, physics and chemistry, $(d)$ natural history.

Nothing has been said thus far about girls' schools. According to the decree which appeared in April, 1907, elementary schools of the first grade and high grade were to be established for girls, but no provision has yet been made for higher education. There are also normal schools for girls to train teachers for the girls' elementary schools. The studies in the girls' schools are the same as those in the boys', with the addition of fine art and needle work, housekeeping, sewing and music. 
As has been described, according to the old system of education degrees were conferred on the successful carididates at the civil service examinations. They are now given to students completing in a satisfactory manner the courses in the new schools. Graduates of the high grade elementary schools may receive the title of "Siutsai" (B.A.), those of the middle schools the title of "Kun-sang" (presentable bachelors), those of the high schools Chü-jên" (M.A.), and those of the university "Chin-shih" (Ph.D.).

Students who have studied in the United States or in Europe, after completing their courses abroad, upon their return to China may attend a special examination in Peking held in the autumn of each year. Upon the result of these examinations they are given Chinese degrees equivalent to those obtained in foreign countries and are made either Chü-jên (M.A.) or Chin-shih (Ph.D.). Thus they put themselves in line with the Chinese educational system, and become eligible for employment in government service.

A word may be said as to the employment of foreign teachers in Chinese schools. When the system was first inaugurated it was necessary to secure good foreign instructors, especially for the middle and high schools. During recent years the number of those employed has diminished, although at no time has it been very large. The attempt was made for a while to replace American and English by Japanese teachers on the ground of economy, but it has not proved very successful.

Rules have been drawn up by the board of education in regard to the employment of foreign instructors, and it is strictly stated that they are not allowed to interfere in school matters outside their own classrooms, and are not permitted to proselytize in regard to religion.

It has often happened that men who have come out from their own countries to accept positions in Chinese schools find on their arrival that they cannot secure students competent to study higher branches, and consequently they have been obliged to spend most of their time in imparting elementary instruction.

As the educational system develops foreign specialists will be needed in greater numbers, for it must be some time before China can provide the teachers needed for university and high school work.

Thus we have given an outline of China's method in revising her educational system. Much might be said in way of criticism. 
Notwithstanding the present inefficiency of the system, we must still wonder at so much being accomplished in so short a space of time, and must sympathize with the Chinese in the innumerable difficulties which they have to surmount. The financial burden of the new system has been very great and has retarded progress.

Perhaps the least pleasing feature has been the unruliness of the student class. The new ideas of liberty and equality have turned the heads of the young men and they have often proved an intractable body to manage. Many a school with bright prospects has been wrecked by rebellion against the authorities on the part of the students. Those placed in charge of the schools of higher grade have, for the most part, been officials with absolutely no experience in educational matters, and naturally they have not commanded the respect of the student body.

As time goes on such matters will be rectified, and we may confidently expect that an efficient educational machine will be constructed in China similar to that already existing in Japan.

Such a revolution as this implies must produce results so farreaching that it is impossible to make an accurate forecast. When enlightening education pervades China, it will produce effects which even the more sanguine can hardly imagine. The next ten or twenty years will prove the value of the new education in China. ${ }^{3}$

- Since this article was written, a report has been received of the Imperial Educational Conference, held at Peking during the past summer. Among the important subjects discussed were the following: (1) The Extension of Primary Education; (2) The Adoption of Compulsory Education for Children from Six to Fourteen Years of Age; (3) Military Training in Public Schools; (4) The Discontinuance of the Study of the Canonical Books In the Primary School; (5) The Discontinuance of Granting Degrees to Graduates from the Schools of Lower Grades. The decisions arrived at are to be submitted to the National Assembly (Tzecheng Guan) at its next session. The holding of such a conference is an evidence of the deep interest felt throughout the Empire in the subject of educational reform. 